\title{
Transdisciplinary research as a support for the planning of disaster risk management actions
}

\author{
Pesquisa transdisciplinar como suporte ao planejamento de ações de \\ gestão de risco de desastres
}

Victor Marchezini $\mathbf{1 , 2}$

DOI: $10.1590 / 0103-11042020$ E2031

\section{Introduction}

Scientific involvement on the topic of disasters has become increasing since the second half of the twentieth century $\mathbf{1}^{\mathbf{1}}$, as have international recommendations on disaster management and, more recently, disaster risk management. Among the main references of the United Nations (UN) on the subject, the International Decade for Natural Disaster Reduction (1990), the Hyogo Framework for Action (HFA) (2005-2015) and the Sendai Framework for Disaster Risk Reduction (SFDRR) (2015-2030) stand out.

The HFA was in force in the period 2005-2015, and its main objective was to increase resilience to disasters and had five priorities for action: i) foster a strong institutional basis to ensure that Disaster Risk Reduction (DRR) be implemented as a priority at national and local level; ii) know and monitor risks in the short and long term; iii) use knowledge, innovation and education for resilience; iv) reduce factors that accentuate risks; and v) strengthen disaster preparedness. In each of these five action priorities, a series of recommendations was made, and it was clear the importance of scientific research to value traditional knowledge and produce new knowledge, as well as to generate subsidies to planning and implementation actions. Although HFA has made important recommendations - such as promoting multisectoral plans, community participation, innovation, people-centered warning systems, valorization of dimensions of gender, age, ethnicity, etc. -, the explicit mention of health issues was marginal - three references to the word 'health', with emphasis on one of the

Monitoramento e Alertas de Desastres Naturais (Cemaden) - São José dos Campos (SP), Brasil. victor.marchezini@cemaden. gov.br

2 Instituto Nacional de Pesquisas Espaciais (Inpe), Programa de PósGraduação em Ciência do Sistema Terrestre - São José dos Campos (SP), Brasil. items of the fourth priority of action, which addressed the need to integrate DRR planning in the health sector and promote the construction and maintenance of safe hospitals ${ }^{2}$.

SFDRR, starting in 2015 and in force until 2030, expands the importance of the participation of many sectors and actors in the topic, especially in the health sector, referenced 75 times throughout the document ${ }^{3}$. The substantial change from HFA to SFDRR occurred in the emphasis on Disaster Risk Management (DRM) actions, which include not only DRR but also prevention so that new risks are not created. To this change in scope, a more detailed characterization of the types of actors in DRR is added - a novelty is the mention of parliamentarians -; research actions aimed at solutions and an interface between science and public policies; disaggregated data on 
vulnerability and natural, biological, environmental, technological and anthropogenic hazards, large and small; the importance of the legal apparatus and governance regimes, as well as the means that support implementation; non-discriminatory participation and technologies, including low-cost technologies. These changes are represented in the four action priorities, which recommend differentiated strategies by national and local governments, regional and global bodies.

The importance of scientific research and the different forms of local, tacit and traditional knowledge is reaffirmed in the first priority: knowing the risk of disaster. However, the relevance of the health sector is also highlighted in the other three priorities: strengthening disaster risk governance, investing in DRR and improving preparedness for disaster response and recovery. Regarding investments in DRR, it is recommended to promote the resilience of national health systems, integrating DRM principles at different levels of care, especially at the local scale. To this end, the need to strengthen the capacities of health sector professionals to work with other sectors is emphasized, as well as to involve communities in improving access to basic health services - understood in a broad sense when embracing food security and nutritional, sexual and reproductive health, housing and education conditions, etc. These actions are foreseen in the different phases of the DRM cycle, including response and recovery measures. In all of these recommendations, scientific participation is seen as fundamental to understand risk drivers, including emerging and complex risks, as well as different scenarios in the short, medium and long term. Science is also invited not only to identify risks, but also to collaborate to find ways and formulate proposals for DRM solutions, together with national, regional and local communities and organizations.

The health sector has taken an important step to put the above recommendations into practice. In 2016, it adopted the Bangkok
Principles for the implementation of the health aspects of SFDRR ${ }^{4}$. There are seven principles that can assist countries in implementation: i) promote the systematic integration of health with DRR policies at the national and sub-national levels; ii) increase cooperation between health authorities and other actors to strengthen countries' capacity in DRM, with the implementation of the International Health Regulations (2005); iii) stimulate public and private investments in DRR actions and emergencies, including health services and infrastructure; iv) integrating DRR into health education programs and strengthening the capacities of health workers on the topic; v) incorporate, in the multi-hazard warning systems, health indicators and risk assessments, disaster data related to mortality, morbidity and disability; vi) support crossborder and cross-sector collaboration, with the sharing of information and science and technology for all types of hazards, including biological ones; and vii) promote the coherence and development of policies, strategies, laws, normative instructions and institutional arrangements at the local and national level.

The contributions of HFA, SFDRR and the Bangkok Principles depend on scientific research to help them find the means of implementation, that is, how to do it. However, how can science contribute to this challenge?

Over the past 15 years, I have worked, as a researcher, in two environments that deal with the topic of disasters: academic and public management. These universes can interact from transdisciplinary research, which involves the involvement of non-academics in the construction and/or development of scientific research. In my view, transdisciplinary research as a support for the planning of DRM actions can be guided around four elements: i) concepts; ii) topics; iii) methods; and iv) data. These four elements can help to establish dialogues between academics and non-academics with the aim of co-producing knowledge and solutions in DRM in the field of public health. 


\section{Concepts}

Concepts allow us to analyze reality in different ways and have implications on the ways of doing science and public policy, as well as to classify the elements that give meaning to the social world, to frame them or not as social problems. Concepts are the object of symbolic disputes in different fields of power and knowledge, such as scientific, political, legal, social. Disaster is one of those concepts that is the target of symbolic struggles. One of these symbolic struggle is limited to its qualification or not as something 'natural'. Meteorology and the media, for example, generally reiterate the use of this adjective, delegating responsibility for meteorological 'events' for damage caused during floods, inundations and landslides ${ }^{5}$. Other approaches consider that the risks of disasters are socio-environmental and territorially produced 'processes', and it is possible to think of ways to reduce them. These critical approaches converge with many recommendations from HFA and SFDRR. However, this debate about the concept of disaster needs to move beyond this dichotomy 'natural x unnatural', 'natural event x socioenvironmental process'.

Derived from the Latin dis (bad, contrary, inappropriate) + aster (astro), the word 'disaster' would represent, if true to its etymological roots, a disgrace caused by the harmful influence of the stars. This word has moved away from its etymological roots, however, it would not make sense to use it in the contemporary context if we consider the types of challenges we witness every day. We experience everyday risks that are no exception, and often the state of exception technique has been used to create fissures in the current legal system in order to frame all problems as public security problems ${ }^{6}$.

However, the risks are produced in the territory, due to the unequal appropriation of resources by a minority and limited access to them. The scarcity - of water, land, food and other services - is less and less controlled by States, as mediators of conflicts between citizens. In the absence of concepts that characterize this chronic state of vulnerability, that is, the social production of fragile conditions and unequal socioenvironmental protection, we continue to use the concepts of disaster and catastrophe. These two terms can be distinguished in relation to the magnitude of damage and loss, with catastrophe being a mega disaster? ${ }^{7}$.

Catastrophes and disasters are characterized by a set of material, environmental, biological, human and psychosocial damages that exceed the local and/or regional and/ or national socio-institutional capacity to cope with the situation that, sometimes, lasts for long months and/or years on end, without the measures of material reconstruction and social recovery being sufficient to reestablish the territorialities prior to the situation of disruption, disruption of usual relations and ways of exercising them, or in a new situation that is considered socially the disaster as overcome. It is because of the insufficient and, sometimes, inefficient response, reconstruction and recovery that I previously referred to a catastrophization process, that is, the

[...] gradual transition from what was initially seen as a disaster to a catastrophe, without any natural hazard, or any 'threatening external agent', resulting mainly from the abandonment of the State ${ }^{8(56)}$.

Today I would say that catastrophization is the opposite of the positivist motto of 'build back better' contained in the Sendai Framework. Or, still, that catastrophization is the cascading disaster ${ }^{9}$, whose effects and impacts irradiate not only along spatial scales - such as the rupture of the dam in the Bento Rodrigues district in Mariana (MG) generating impacts beyond the Doce River 
Basin towards the Abrolhos Island, south of Bahia - as well as in time scales, from days to decades. The complexity of these catastrophes throughout space, face-to-face and virtual, and time, present and future, requires us to review the concepts and ways in which we plan DRM actions. We need to get rid of those self-help phrases that the Sendai Framework makes us captivate: this illusion that we will learn from the disaster and that these 'lessons learned' - to use an expression from the Sendai Framework itself - will be sufficient, with the promise of security if a 'new disaster' happens again. It is necessary to get ready for what was previously unthinkable, just as students and teachers at a Kamaishi High School, in Japan, did when they realized that the contingency plan would no longer be enough: it was necessary to abandon the roof of the school building and run to higher places because the size of the tsunami wave, in March 2011, would exceed all the predictions and risk analysis previously made ${ }^{10}$.

In addition to debating the concept of disaster, it is necessary to reopen discussions on what is understood by risk of disaster and who is at risk. Traditionally, the disaster risk equation disseminated in scientific literature and in civil defense training courses has considered that disaster risk (R) is defined by the interaction between the hazard $(\mathrm{H})$ enhanced/multiplied by the vulnerability (V). Or should we reverse this equation and consider that, in fact, vulnerability is enhanced by the hazard? This equation is not only susceptible to a classic mathematical interpretation in which the change in the order of factors does not change the product. Changing the order of factors makes all the difference to how we understand disaster risk as a social problem, and it may be necessary to assign different weights to each of the factors. In this regard, we need 'social mathematicians' willing to engage with other specialists in collective health, humanities and social sciences.

There is the need to discuss more about vulnerability. This is defined as the potential to suffer losses and damages and, in addition to economic poverty, it considers other dimensions of deprivation, such as lack of physical capacity, insecurity, social isolation, lack of political power"1. There are several publications and literature reviews on the concept of vulnerability, which highlight quantitative and qualitative methodologies, in different spatial and temporal scales and phases of the DRM cycle, some participatory and some not, some focused on the specificities of social groups in relation to dimensions of gender, age, mobility, type of disability ${ }^{\mathbf{1 2}}$. Other approaches expand the use of the concept to analyze institutional, economic, political, educational vulnerability ${ }^{13}$. Some perspectives seek to understand 'who' or 'what' is vulnerable, 'where', 'when'. Others approach vulnerability as something processual, that is, a diachronic analysis. In this case, it is important to understand: 'why' are some people more vulnerable than others?

The 'pressure and release model' seeks to understand the root causes of vulnerability (for example, income inequality) and 'dynamic pressures' that accentuate them (dependence on financial capital, GDP dependent on the fluctuation of commodity prices) and lead to living in unsafe conditions (living in precarious housing susceptible to landslides) in the face of hazards (figure 1) ${ }^{\mathbf{1 4}}$. 


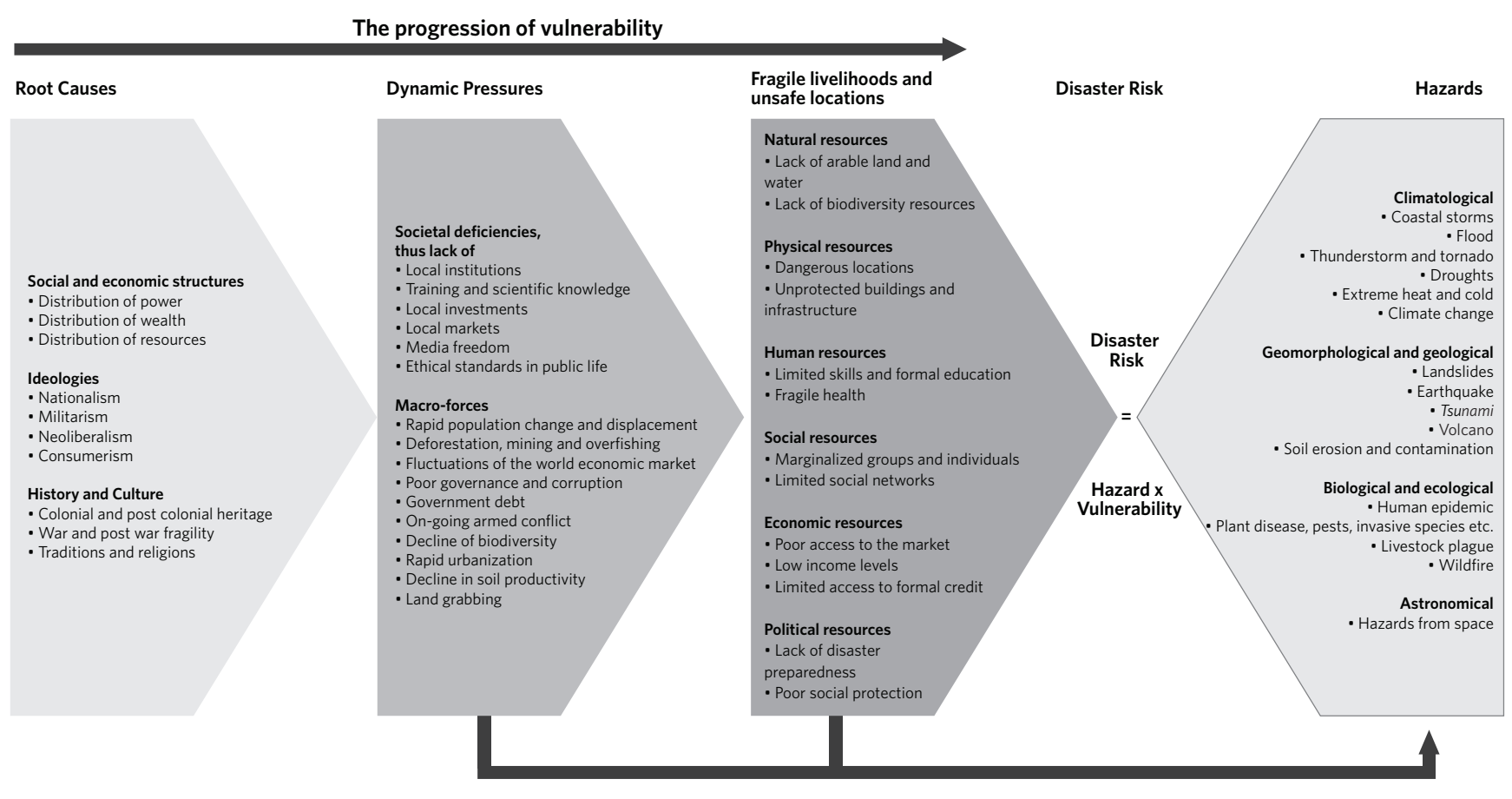

Accentuation of some (not all) hazards

In this processual approach, it is necessary to discuss the relationship between disasters, economic growth and development models. Economic growth and development are not synonymous. Economic growth is a variation in the Gross Domestic Product (GDP), a percentage change in the measured economic activity ${ }^{15}$. Development is a social project to improve living conditions, a healthy environment, guarantee dignity, exercise citizenship, reduce inequality and misery ${ }^{16}$. Although there is a growing scientific and social recognition that disasters hamper economic development, it is necessary to recognize that disasters can be the consequence of bad economic growth projects and the consequent dynamic pressures they cause ${ }^{17}$. Disasters and/or crimes and/or extended work accidents associated with the rupture of mining tailings dams in Mariana (MG) (2015) and Brumadinho (MG)
(2019) had, as dynamic and cyclical pressure factors, the high mining commodity prices and the quest to produce as much as possible to generate profitability, or rather, prioritized economic growth at any cost, even with full knowledge of the dams' insecure conditions. The countless dam ruptures recorded in the Country ${ }^{\mathbf{1 8}}$ reveal that the modus operandi is to generate and concentrate profitability, creating risks and producing disasters downstream. Unfortunately, this ethos is present in other economic sectors, in its investors and shareholders who finance the activities of companies that generate risks of disasters and large environmental liabilities. The complexity of these risks and damage that happened, extensive in time, as we continue to see in the Doce River Basin and now in the region of Brumadinho (MG), reveals that it is insufficient to delegate only to civil protection and 
defense the responsibility for DRM actions. In addition to creating civil defense units in just over $40 \%$ of the municipalities where it does not even exist on paper, improving the working conditions of municipal civil defenses and their professional staff'19,20, new disaster risk governance and disaster management mechanisms that share power and responsibilities are needed, as suggested in the 100-page report produced by the Getulio Vargas Foundation to support the National Plan for Risk Management and Disaster Response (2012-2014).

It is necessary to consider that interventions on territories for appropriation of resources and maximization of gains also change the patterns of natural phenomena, such as rainfall, floods, droughts, desertification, etc. If there are people occupying these susceptible areas, they are exposed and may be more vulnerable, that is, they are more fragile and prone to suffer damage due to their income conditions, the characteristics of the occupation, the type of housing, the degree of population density. Sometimes, people are not vulnerable and have lived for years with that environmental phenomenon. A gradual flooding in the Amazon or a drought are not a priori hazards, because they are part of the climate and water cycles.

For hazards, the UN office's terminology for RRD considers phenomena that may trigger a probable harm ${ }^{21}$. These phenomena are classified according to their origin: hydrometeorological (rain, tornadoes, droughts, floods, etc.); technological (poorly planned/ poorly built dams, nuclear plants, among others); biological (viruses, bacteria); geological (earthquakes) and environmental (air pollution, sea level rise). Certain areas may be more or less susceptible to some phenomena - such as, for example, droughts - due to the characteristics of the climate, soil, relief, vegetation. They can also present a combination of hazards and threats that can be altered by anthropic interventions, not only at the local scale. Successive elevations of tailings dams may be in watersheds susceptible to extreme precipitation events. The eventual rupture of these dams can make unviable any preventive evacuation plan for the elderly and sick due to the speed and volume of the wave of mud mobilized. We must recognize that our knowledge of the risks is still very incipient.

The adoption of the disaster risk equation by managers and/or scientists ends up denying two other variables: the social capacities to cope with risk situations and the importance of risk mitigation policies. Sometimes, the existence of community warning systems can help to increase the capacity for self-protection, in other words, to live with risks, to know how to reduce their exposure to hazards. Before HFA, this concept of capacities was treated as the opposite of vulnerability and used in the stages of prevention, preparedness and response. More recently, the concept of resilience has been used as a synonym for capacity, although it was originally applied to reconstruction and recovery situations - then conceptualized as social strategies to face, absorb and deal with the impacts of disaster. Currently, the concept has been applied in the disaster field to refer not only to people but also to infrastructure, cities $^{22}$. Some approaches criticize the use of the concept of resilience because they consider that it depoliticizes the social contexts that limit individuals' access to resources, as if they could 'be resilient' on equal terms, and there were no inequalities and vulnerabilities prior to the disaster ${ }^{23}$.

In addition to this individual capacity, policies for risk mitigation on a large scale are important, as they involve structural actions that contribute to reducing not only exposure, but also vulnerability, through policies of access and distribution of water, of generation income, guarantee of food and nutritional sovereignty, provision of housing in a safe place. In general, the adoption of the traditional risk equation conceives the disaster as a 'one-time event', that is, it does not consider the importance of public risk 
mitigation policies on a large scale, nor the social factors that led to the social production process of vulnerability conditions. Another important aspect is that DRM is guided by problems to be reduced and/or avoided, and not by the promotion of other values such as sustainability.

Considering an expanded version of the risk equation, representing it mnemonically as Disaster Risk = Hazard x [(Vulnerability/ Capacity)-Mitigation] ${ }^{14}$, implies reflecting and acting on the social production of risk. From this expanded equation, it is also possible to talk about the institutions that should have differentiated responsibilities for DRR actions, adding new organizations with competencies, in a decentralized DRM system. DRM actions involve non-structural activities, such as the adoption of warning systems, educational policies, building codes that consider the risks, as well as structural measures, through urban drainage works, provision of resistant dwellings in areas not susceptible to hazard and/or threat etc. This set of measures requires governance mechanisms. In the scope of the DRM, governance is understood as the process of defining competences and coordinating organizations, public and private actors, laws, regulations and standards in order to reduce the risks of disasters and their impacts ${ }^{24}$.

In addition to the concepts discussed above, transdisciplinary research can nourish itself with concepts from other areas of knowledge, in addition to thinking about them from the different topics and phases of DRM. From the point of view of my practical work at the National Center for Monitoring and Early Warning of 'Natural' Disasters (Cemaden), the concept of the warning system and its conception based on four axes - risk knowledge, monitoring, communication/education and response capability $\mathbf{2 5}$ - have been important for research between areas of knowledge (interdisciplinary) and those involving civil defense agents, youth and other actors and non-academic sectors (transdisciplinary).

\section{Topics}

In a single disaster, several scientific research themes can be found: social, environmental, political, economic, ethical, cultural, business, religious, etc. A single disaster can generate multiple impacts at different spatial and temporal scales, and demand research projects that go beyond the conventional years of duration adopted by funding agencies.

As many actors converge towards the scene of emergency and disaster, a fundamental need is to establish a code of conduct; and there is a need for research on this. Non-governmental organizations that deal with response actions, providing temporary shelters and structuring refugee camps have established, through the Sphere Project, a Humanitarian Charter with a series of recommendations on the topic, in order to avoid adopting differentiated reference criteria by institutions, such as, for example, minimum shelter space for each family or domestic group ${ }^{26}$. Some previous editions of the Sphere Project manual had a Portuguese version and could be complemented with other documentary materials, such as the 'Rio de Janeiro State Civil Defense Shelter Manual'27, and scientific publications on the topic ${ }^{\mathbf{2 8}}$. More research is needed on temporary shelters and refugee camps in Brazil. Even internationally, the recognition of the topic is incipient, and its appreciation fluctuates in the discussion agenda. Despite the publication, in the 1970s, of the book 'Shelter After Disasters' ${ }^{\mathbf{2 9}}$, it is surprising to see that the HFA did not mention the word shelter and that the current Sendai Framework reports the topic only once, without mentioning the Humanitarian Charter.

The code of conduct is also necessary for researchers working in emergency and disaster scenarios. In a recent article published in 'Nature', researchers reported the impacts that the arrival of external researchers to the affected locations can cause, for example, the fatigue caused by requests for interviews and filling in questionnaires ${ }^{30}$. These codes 
of conduct could also be applied to organizations active in response, especially when they involve civilian and military organizations health teams, social assistance, military and civilian firefighters -, volunteers, press agencies. These codes are also necessary between military organizations acting together - Fire Department, Environmental Military Police, Armed Forces - as they also have conflicts among themselves, as seen in the disaster in the Itajaí Valley (Santa Catarina, Brazil) ${ }^{31}$. How could public health contribute to research to formulate these codes of conduct?

In addition to actions to respond to emergencies and disasters, researches in the field of reconstruction and recovery are essential. In disasters, new precarious territorialities are configured, that is, new forms of appropriation of space, organization and meaning of its place in the social world ${ }^{32}$. The precariousness of these territorialities allows us to identify that the disaster can have a continuity if public policies for response, reconstruction and recovery in disasters are below the minimum necessary for the social life of the survivors ${ }^{\mathbf{3}}$. As flood and landslide survivors, they become abandoned in disasters as social assistance, psychosocial care, housing reconstruction, and job creation policies are not implemented. The images of the approximately 60 homeless families pop up in my memory during the June 2010 flood in União dos Palmares (Alagoas, Brazil), living in about 140 tents built on an area on the BR-104 highway, far from health units and schools, under the daytime heat of canvas tents, without proper toilets and adequate lighting, open sewage, etc. These cases of precarious territoriality and social abandonment in disasters are replicated from the north to the south of the Country34. What types of transdisciplinary research has collective health carried out in the course of reconstruction and recovery processes? To what extent have the results of these surveys improved public policies and other fields of knowledge, such as disaster law?

In addition to research on disasters and on the topic, research in the field of prevention and DRR is indispensable. Interdisciplinary and transdisciplinary researches are essential to develop conceptual and governance models for disaster risks associated with different types of hazards. With regard to droughts, scientific and institutional actions are not restricted to drought monitoring and response policies, such as the provision of water trucks, but include a series of activities in relation to risk awareness, mitigation actions between different organizations ${ }^{35}$. In relation to fires, knowledge about risks, forms of monitoring and communication, as well as public mitigation policies, generate several opportunities for transdisciplinary research ${ }^{36}$. In the state of Acre, for example, the fires and forest fires recorded in 2005 had impacts in several sectors. In the health sector, over 400 thousand people were affected by air pollution and smoke ${ }^{37}$. Instead of just putting out forest fires and fires and/or punishing transgressors, alternative policies were also sought to facilitate the clearing of pasture for use in agriculture. Instead of fire, subsidized use of small tractors to assist in cleaning. In addition to forest fires and fires, the state of Acre also has to deal with other hazards: the state recorded recurrent floods in 2012, 2014 and 2015, with cases that impacted several sectors, including public health. The complexity and, sometimes, the combination of these hazards, associated with growing vulnerabilities in the territory, demand the discussion of transdisciplinary research agendas in DRM.

The challenges brought by disasters require scientists, managers, third sector, civil society to prioritize network initiatives in a short (next 2 years), medium (5 years) and long term (10 years) horizon. Citizens, managers and scientists can evoke a wide range of themes that relate to risks and disasters. In the Brazilian context, networks of DRR researchers make efforts to build thematic areas ${ }^{38}$. Other examples of collaborative networks - some interdisciplinary and others transdisciplinary - are the Risk Management Network of the Córrego 
Dantas Basin (Reger-CD) ${ }^{39}$, the Independent Environmental Impact Assessment Group (Giaia) ${ }^{\mathbf{4 0}}$ and ComRIOComMAR, the latter two created after the dam burst in Mariana (MG). Do these collaborative networks involve public health professionals? Despite these efforts, it is interesting to highlight that disaster science is not a thematic area of the National Council for Scientific and Technological Development (CNPq), that there is no regular financing line and that scientific production is still incipient in Brazil ${ }^{41}$. The construction of transdisciplinary research agendas can help to plan the training of human resources on the topic, allow the organization and sharing of historical series of databases, besides helping in the management of scientific knowledge on topics of national interest. This management can assist in the quick search for specialists who can support the discussion on emerging and emergency issues, as seen in the Brumadinho (MG) catastrophe in 2019, when technicians had to travel from Israel to Brazil to assist in the rescue of those buried by the mud from Vale's dam. Thinking about 'with whom' to talk to identify 'what' is necessary to research are important steps in finding ways about 'how to do'.

\section{Methods}

To the wealth of themes, alternative ways of approaching them can be added, with methods that combine the dialogue between forms of knowledge - traditional, tacit, scientific around common challenges. The different areas of science need to recognize traditional and tacit knowledge as a form of knowledge, in addition to reducing the inequalities of power between the areas of science and within the same area, with the hierarchies and mechanisms of distinction that are created. This field of power becomes even more complex in the face of the demand for research projects involving actors from developed and developing countries, from public and private organizations, to which is added the charge for production of articles, definition of authorship, intellectual property, and projects that have an impact, although it remains unclear what this means ${ }^{\mathbf{4 2}}$. In these hierarchies that are created, there is an influence on the definition of methods. In the USA, it is common for interdisciplinary projects in earth system science to be coordinated by scientists in the field of natural science, to define research questions and, from there, include a humanities professional 'to do the social part of the project', in a clear relationship of subordination between the sciences ${ }^{\mathbf{4 3}}$. How to reduce power inequalities between sciences and between traditional and scientific forms of knowledge in order to formulate research methods?

In the field of disaster science, there are some interdisciplinary methods such as the Forensic Investigations of Disasters, which proposes common research questions to be answered in an interdisciplinary way ${ }^{\mathbf{4 4}, \mathbf{4 5}}$. However, the methods can also be transdisciplinary, that is, involve the participation of non-scientists in different stages of the research, or even in the construction of the research and its phases. In this regard, action research methodologies seek to build research priorities based on the practical challenges presented by the interlocutors in their daily lives ${ }^{46}$. The action research is a type of social research

[...] conceived and conducted in close association with an action or with the resolution of a collective problem and in which researchers and participants representing the situation of the reality to be investigated are involved in a cooperative and participatory manner47(14).

These action research methods can be developed at different stages of the disaster and DRM. Interactive 3D models, such as social technologies for representing social relations in a miniaturized territory, have already been used to discuss education and disaster 
prevention ${ }^{\mathbf{4 8}}$, for discussing and organizing the rules of living in temporary shelters, formulating plans to adapt to climate change ${ }^{49}$. Several initiatives in participatory risk mapping have also been used ${ }^{\mathbf{5 0}}$, as well as methodologies involving cooperative games, theater, photographs, oral history, comic books, drills ${ }^{51}$. One challenge is how to build participatory methodologies for assessing damage and $\operatorname{loss}^{52}$, including for quantifying deaths that have occurred in the wake of the disaster ${ }^{53}$ or to collect perishable data, in other words, that need to be collected in situ before they are lost.

Sometimes, the methods allow non-scientists to be involved in the stage of collecting and analyzing data for scientific purposes, in a modality known as citizen science. Very widespread in some areas of knowledge such as biology and ecology, the citizen science approach is becoming popular in Brazil ${ }^{54}$. Within the scope of risk and disaster science, there are still few studies using the approach of this method ${ }^{55}$. The potentials are diverse. In Zimbabwe, for example, this approach was used to build a community malaria alert system, connecting health workers and people from communities ${ }^{56}$. In Brazil, it has been used to connect high schools, civil defense and community representatives in activities to generate knowledge about the risk and proposition of small interventions in DRR ${ }^{\mathbf{5 7}, 58}$. How could scientists and public health professionals collaborate to build these methods?

\section{Data}

Methods allow creating opportunities for the production of data, information and knowledge. Data, information and knowledge are not synonymous. For example: it is common for us to hear "it was $80 \mathrm{~mm}$ of rain in 24 hours". What does this $80 \mathrm{~mm}$ data mean in 24 hours? Data can be a measure or a representation, that is, they are quantitative and/ or qualitative in nature. One way to measure rain is in millimeters. When these data are interpreted by the people involved in the research, they become endowed with sense/ meaning, that is, they become information. When I understand that 80 millimeters is 80 liters per square meter, I have an information. When I adopt a method to systematically collect this data and information, for example, daily, at 9 am over the course of a year, and I identify that, during that period of analysis, there were 120 occurrences of rain above $80 \mathrm{~mm}$ in 24 hours, I generated knowledge about the distribution and intensity of rain over a period. If I choose to associate these rain values with the occurrence of floods, inundations and/or landslides and the damages that have occurred - such as post-flood leptospirosis cases, one can also produce knowledge about the impacts on hydrometeorological events, in addition to discussing ways to reduce them. Data, information and knowledge are essential to diagnose the main problems, understand them and dialogue about which DRM planning actions are necessary.

Data governance is considered a fundamental aspect for DRM actions. In 2017, the UN published a global report that provided a diagnosis of the availability of data for monitoring indicators from the Sendai Framework ${ }^{59}$. The document focused on four main aspects: i) data availability; ii) quality; iii) accessibility; and iv) applicability for decision making. These data need to have consistency, reliability, comparability and standardized formats for the monitoring of the goals of the Sendai Framework in order to, accordingly, also contribute to the indicators of the Sustainable Development Goals (SDGs). In that aforementioned report, 87 member states - 17 on the American continent, Brazil being one of them - analyzed the availability of their data, the needs for improvement and the resources needed to implement them. Of this group of countries, 26 (30\%) use DesInventar, a methodology with a computational tool for building databases on disasters ${ }^{60}$, including, as recommended by the Sendai Framework, 
recurring 'small' disasters. Brazil is the only country in South America that has not yet adopted this methodology.

Another point emphasized by the report is the existence of disaggregated data, considered essential to understand the risk of disaster, the first priority of the Sendai Framework. Almost all participating countries $(90 \%)$ reported having data by type of hazard. The availability of disaggregated data worsens when the need is to understand human damage by age, sex, disability, income. In Brazil, for example, the change from the Damage Assessment Form (Avadan) to the Disaster Information Form (Fide) resulted in the suppression of human damage by age group. What were the implications of this change for the planning of DRM actions in the field of public health?

Accessibility to data was another challenge identified. Data may exist, but access to it can be difficult due to conflicts, power struggle, personalization, lack of trust, etc. Only $38 \%$ of countries reported that their loss databases are publicly accessible, while $45 \%$ of them simply did not answer this question. Regarding the history of the database, $41 \%$ of the countries reported having records for the period 2005-2015.

Other problems pointed out were the data format, the existence of protocols for standardization and data sharing, the availability of geospatial data with respective metadata. In Brazil, Spatial Data Infrastructure (Inde) already houses some databases and documents on the topic of disasters, but there is still a need to create 'interoperability' with other platforms, such as the Disaster Information System (S2ID), databases from the Geological Survey of Brazil (CPRM), from Cemaden, from the Ministry of Health. The challenge is even greater if we think about the potential databases that dissertations and theses could provide at the end of their work, as well as the collaborative data that can be provided via applications and other crowdsourcing systems. Which sectors could benefit from this sharing? What would be the cost savings for collection and analysis? What types of information and knowledge could be generated?

Data can generate the opportunity to foster a culture of evidence-based decision-making, with gradual learning about data collection and analysis procedures, increasing the engagement of non-scientists in stages of transdisciplinary research. However, it is necessary to avoid a romanticized vision of transdisciplinary research, and ensure mechanisms of scientific independence and autonomy over data, information and knowledge generation, avoiding political interference with the results of transdisciplinary research. Therefore, it is necessary not only to work on the organizational culture for learning the law of access to information, but also to create mechanisms and models of transdisciplinary research that allow to acclimate to constructive criticism.

\section{Acknowledgments}

I am grateful to the São Paulo Research Foundation (Fapesp). The opinions, conclusions and recommendations expressed in this material are those of the author and do not necessarily reflect the views of the financing institutions and to which he belongs.

\section{Collaborator}

Marchezini V (0000-0002-1974-0960)* is responsible for preparing the manuscript. 


\section{References}

1. Marchezini V. As ciências sociais nos desastres: um campo de pesquisa em construção. Rev. Brasileira Inf Bibliog. Ciênc. Soc. 2018; (83):43-72.

2. United Nations International Strategy for Disaster Reduction. Hyogo Framework for Action 2005-2015: Building the resilience of nations and communities to disasters. Geneva: UNISDR; 2005

3. United Nations International Strategy for Disaster Reduction. Sendai framework for disaster risk reduction 2015-2030. Geneva: UNISDR; 2015.

4. United Nations International Strategy for Disaster Reduction. Bangkok Principles for the implementation of the health aspects of the Sendai Framework for Disaster Risk Reduction 2015-2030. Geneva: UNISDR; 2016.

5. Marchezini V. A produção simbólica dos desastres naturais: composições, seleções e recortes. Interseções. 2014; (16):174-196.

6. Marchezini V. Processos de recuperação em desastres: discursos e práticas. São Carlos: RiMa; 2014.

7. Quarantelli E. Catastrophes are Different from Disasters: Some Implications for Crisis Planning and Managing Drawn from Katrina [internet]. 2006 [acesso em 2008 jun 30]. Disponível em: https://items.ssrc. org/understanding-katrina/catastrophes-are-different-from-disasters-some-implications-for-crisis-planning-and-managing-drawn-from-katrina/.

8. Marchezini V. Dos desastres da natureza à natureza dos desastres In: Valencio N, Siena M, Marchezini V, et al. Sociologia dos Desastres: construção, interfaces e perspectivas no Brasil. São Carlos: RiMa; 2009, p. 48-57.

9. Alexander D, Pescaroli G. What are cascading disasters? UCL Open: Environment [internet]. 2019 [acesso em 2019 dez 1]; (1):3. Disponível em: https://dx.doi. org/10.14324/111.444/ucloe.000003.
10. Katada T, Kanai M. The School Education to Improve the Disaster Response Capacity: A Case of "Kamaishi Miracle”. J Disast. Research. 2016; 11(5):845-856.

11. Chambers R. Vulnerability, coping and policy. IDS bulletin [internet]. 1989 [acesso em 2019 jul 23]; 20(2):1-7. Disponível em: https://onlinelibrary.wiley.com/doi/ abs/10.1111/j.1759-5436.1989.mp20002001.x.

12. Wisner B. Vulnerability as Concept, Model, Metric, and Tool. Oxford Research Encyclop. Nat. Hazard Scien. [internet]. 2016 [acesso em 2019 jul 23]. Disponível em: https://oxfordre.com/naturalhazardscience/view/10.1093/acrefore/9780199389407.001.0001/ acrefore-9780199389407-e-25.

13. Marchezini V. Redução de vulnerabilidade a desastres: dimensões políticas, científicas e socioeconômicas. Waterlat-Gobacit Network Working Papers [internet]. 2015 [acesso em 2019 jul 23]; 2(17):82-102. Disponível em: http://waterlat.org/WPapers/WPSATAD217.pdf.

14. Wisner B, Gaillard JC, Kelman I. Framing disaster: Theories and stories seeking to understand hazards, vulnerability and risk. In: Wisner B, Gaillard JC, Kelman I. The Routledge handbook of hazards and disaster risk reduction. London: Routledge; 2012. p. 18-34.

15. Vieira ET, Santos MJ. Desenvolvimento econômico regional - uma revisão histórica e teórica. Rev. Bras. Gestão e Desenvolvimento Regional [internet]. 2012 [acesso em 2019 jul 23]; 8(2):344-369. Disponível em: https://www.rbgdr.net/revista/index.php/rbgdr/article/view/679.

16. Carvalho JM. Cidadania no Brasil: o longo caminho. Rio de Janeiro: Civilização Brasileira; 2002.

17. Lavell A. Prefácio. In: Marchezini V, Wisner B, Londe LR, et al. Reduction of Vulnerability to Disasters: from knowledge to action. São Carlos: RiMa; 2017. p. 21-26.

18. Gonçalves JC, Marchezini V, Valencio NFLS. Desas- 
tres relacionados a colapsos de embalses en Brasil: aspectos sociopolíticos de una seguridad ilusoria. Estud. Sociol. [internet]. 2012 [acesso em 2019 jul 24]; 30(90):773-804. Disponível em: https://estudiossociologicos.colmex.mx/index.php/es/article/view/93/93.

19. Dutra AS, Gonçalves RS. A atuação dos assistentes sociais nos órgãos municipais de Proteção e Defesa Civil. Em Pauta [internet]. 2012 [acesso em 2019 jul 24]; 37(14):106-125. Disponível em: https://www.e-publicacoes.uerj.br/index.php/revistaempauta/article/view/25388.

20. Londe LR, Soriano E, Coutinho MP. Capacidades das instituições municipais de Proteção e Defesa Civil no Brasil: desafios e perspectivas. Rev Depart Geo. (USP) [internet]. 2015 [acesso em 2019 jul 24]; 30:7795. Disponível em: http://www.revistas.usp.br/rdg/ article/view/98715/107757.

21. United Nations International Strategy for Disaster Reduction. Terminology: Basic Terms of Disaster Risk Reduction. [internet]. 2017 [acesso em 2019 jul 23]. Disponível em: https://www.unisdr.org/we/inform/terminology\#letter-e.

22. Manyena SB. The concept of resilience revisited. Disasters. 2006; 30(4):433-450.

23. Macias JMM. Critica de la noción de resiliencia en el campo de estudios de desastres. Rev Geo. Venez. 2015; 56(2):309-325.

24. Tierney K. Disaster governance: social, political, and economic dimensions. Annual Rev Environ. Resources. 2012; (37):341-363.

25. Marchezini V, Londe LR. Sistemas de alerta centrados nas pessoas: desafios para os cidadãos, cientistas e gestores públicos. Rev Gestão Sustentab. Amb. 2018; (7):525-557.

26. Sphere Association. The Sphere Handbook: Humanitarian Charter and Minimum Standards 4. ed. Geneva: Sphere; 2018.

27. Rio de Janeiro. Secretaria de Estado da Defesa Civil.
Administração para Abrigos Temporários. Rio de Janeiro: SEDEC-RJ; 2006.

28. Marchezini V. Campos de desabrigados - a continuidade do desastre. São Carlos: RiMa; 2014.

29. Davis I, Thompson P. Krimgold F. Shelter after disaster. 2. ed. [internet]. Geneva: IFRC; OCHA; 2015. [acesso em 2019 jul 23]. Disponível em: https://www. ifrc.org/Global/Documents/Secretariat/201506/Shelter_After_Disaster_2nd_Edition.pdf.

30. Gaillard JC, Peek L. Disaster-zone research needs a code of conduct. Nature. 2019; (575):440-442.

31. Menezes JGR. A tragédia do Morro do Baú. Blumenau: Nova Letra; 2009.

32. Haesbaert R. O mito da desterritorialização: do "fim dos territórios” à multiterritorialidade. Rio de Janeiro: Bertrand Brasil; 2004.

33. Marchezini V. La producción silenciada de los 'desastres naturales’ en catástrofes sociales, Rev. Mex. de Sociología [internet]. 2014 [acesso em 2019 jul 23]; 76(2):253-285. Disponível em: http://www. scielo.org.mx/scielo.php?script=sci_arttext\&pid $=$ S0188-25032014000200004.

34. Valencio N, Siena M, Marchezini V. Abandonados nos desastres: uma análise sociológica de dimensões objetivas e simbólicas de afetação de grupos sociais desabrigados e desalojados / Norma Valencio. Brasília, DF: Conselho Federal de Psicologia; 2011.

35. Cunha APMA, Marchezini V, Lindoso DP, et al. The challenges of consolidation of a drought-related disaster risk warning system to Brazil. Rev. Sust. Deb. [internet]. 2019 [acesso em 2019 jul 23]; (10):43-76. Disponível em: http://periodicos.unb.br/index.php/ sust/article/view/19380.

36. Anderson LO, Marchezini V, Morello TF, et al. Modelo conceitual de sistema de alerta e de gestão de riscos e desastres associados a incêndios florestais e desafios para políticas públicas no Brasil. Territorium [internet] 2019 [acesso em 2019 jul 23]; (26):43- 
61. Disponível em: https://impactum-journals.uc.pt/ territorium/article/view/6427.

37. Brown IF, Schroeder W, Setzer A, et al. Monitoring fires in southwestern Amazonia rain forests. EOS Transactions. [internet] 2006 [acesso em 2019 jul 24]; (87):253-264. Disponível em: https://agupubs.onlinelibrary.wiley.com/doi/abs/10.1029/2006EO260001.

38. Freitas M, Portella S. A redução de risco e desastres e os desafios da criação e ação de uma rede brasileira de pesquisa. In: Marchezini V, Wisner B, Londe LR, et al. Reduction of Vulnerability to Disasters: from knowledge to action. São Carlos: RiMa; 2017. p. 601-620.

39. Freitas LE, Coelho Netto AL. Reger Córrego Dantas: uma ação coletiva para enfrentamento de ameaças naturais e redução de desastres socioambientais. Ciênc. Trópico. 2016; (40):165-190.

40. Mariuzzo P, Barata G. Desastre ambiental incentiva monitoramento alternativo de ciência aberta. Ciência Cultura [internet]. 2016 [acesso em 2019 dez 1]; 68(1):06-07. Disponível em: http://cienciaecultura.bvs.br/scielo.php?script=sci_arttext\&pid $=$ S0009-67252016000100003.

41. Rodrigues AC, Gunther WMR, Vasconcellos MP, et al. Delineamento da produção científica sobre desastres no Brasil no início deste século. Desenv. Meio Ambiente [internet] 2015 [acesso em 2019 jul 23]; (34):6173. Disponível em: https://revistas.ufpr.br/made/article/view/38992.

42. Oliver K, Cairney P. The dos and don'ts of influencing policy: a systematic review of advice to academics. Palgrave Communications. 2019; 5(21):1-23.

43. Brulle RJ, Dunlap RE. Sociology and Global Climate Change. In: Dunlap RE, Brulle RJ. Climate change and society: Sociological perspectives. New York: Oxford University Press; 2015.

44. Oliver-Smith A, Alcántara-Ayala I, Burton I, et al. Forensic investigations of disasters (FORIN): A conceptual framework and guide to research. Beijing: Integrated Research on Disaster Risk; 2016.
45. Oliver-Smith A, Alcántara-Ayala I, Burton I, et al. A construção social do risco de desastres: em busca das causas básicas. In: Marchezini V, Wisner B, Londe LR, et al. Reduction of Vulnerability to Disasters: from knowledge to action. São Carlos: RiMa; 2017. p. 97-114.

46. Gibson T, Wisner B. 'Let's talk about you...': Opening space for local experience, action and learning in disaster risk reduction. Dis. Prev. and Man. [internet]. 2016 [acesso em 2019 jul 23]; 25(5):664-684. Disponível em: https://www.emerald.com/insight/content/ doi/10.1108/DPM-06-2016-0119/full/html.

47. Thiollent M. Metodologia da Pesquisa-Ação. São Paulo: Cortez; 1985.

48. Valencio N, Siena M, Marchezini V. Maquetes Interativas: fundamentos teóricos, metodológicos e experiências de aplicação. In: Valencio N, Siena M, Marchezini V, et al. Sociologia dos Desastres: construção, interfaces e perspectivas no Brasil. São Carlos: RiMa; 2009. p. 199-215.

49. Valencio NFLS, Siena M, Marchezini V, et al. Implicações das mudanças climáticas no contexto insular africano: experiências educativas voltadas para o caso de São Tomé e Príncipe In: Valencio N, Ribeiro WC, organizadores. São Tomé e Príncipe, África: desafios socioambientais no alvorecer do séc. XXI. São Carlos: RiMa; 2010. p. 123-156. (v. 2.).

50. Marchezini V, Iwama A, Andrade MRM, et al. Geotecnologias para prevenção de riscos de desastres: usos e potencialidades dos mapeamentos participativos. Rev Brasileira Cartog. 2017; 69(1):107-128.

51. Marchezini V, Mendonça MB, Sato AM, et al. Educação para redução de riscos e desastres: experiências formais e não formais no Estado do Rio de Janeiro. Anuário Inst. Geociênc. 2019; 42(4):102-117.

52. Zhouri A, Valencio N, Oliveira R, et al. O desastre da Samarco e a política das afetações: classificações e ações que produzem o sofrimento social. Ciênc. Cultura; 2016; 68(3):36-40.

53. Kishore NMPH, Marqués MPD, Mahmud A, et al. 
Mortality in Puerto Rico after Hurricane Maria. New

Engl. J. Med. 2018; (5):1-9.

54. Albagli S, Maciel ML, Abdo AH. Ciência aberta, questões abertas. Brasília, DF; Rio de Janeiro: IBICT; UNIRIO; 2015.

55. Marchezini V, Horita FEA, Matsuo PM, et al. A Review of Studies on Participatory Early Warning Systems (P-EWS): Pathways to Support Citizen Science Initiatives. Front. Earth Sci. [internet]. 2018 [acesso em 2019 jul 23]; 6(184):1-18. Disponível em: https://www.frontiersin.org/articles/10.3389/feart.2018.00184/full.

56. Macherera M, Chimbari MJ. Developing a community-centred malaria early warning system based on indigenous knowledge: Gwanda District, Zimbabwe. Jàmbá [internet]. 2016 [acesso em 2019 jul 23]; 8(1):a289. Disponível em: https://jamba.org.za/index. php/jamba/article/view/289.

57. Marchezini V, Trajber R, Olivato D, et al. Participatory early warning systems: youth, citizen science and intergenerational dialogues on disaster risk reduction in Brazil. Inter. J Disaster Risk Sci. [internet]. 2017 [acesso em 2019 jul 23]; 8(4):390-401. Disponí- vel em: https://link.springer.com/article/10.1007/

s13753-017-0150-9.

58. Trajber R, Olivato D. A escola e a comunidade: ciência cidadã e tecnologias digitais na prevenção de desastres. In: Marchezini V, Wisner B, Londe LR, et al. Reduction of Vulnerability to Disasters: from knowledge to action. São Carlos: RiMa; 2017. p. 531-550.

59. United Nations. Disaster-related Data for Sustainable Development/Sendai Framework Data Readiness Review 2017. Genebra: Global Summary Report; 2017.

60. Muñoz VA, Marchezini V, Santos LBL, et al. DesInventar: ferramenta conceitual e plataforma computacional para sistematização de dados e suporte à pesquisa de risco e desastres. In: Marchezini V, Wisner B, Londe LR, et al. Reduction of Vulnerability to Disasters: from knowledge to action. São Carlos: RiMa; 2017. p. 311-334.

Received on $07 / 24 / 2019$

Approved on 01/13/2020

Conflict of interests: non-existent

Financial support: São Paulo Research Foundation (Fapesp). Grant number: 2018/06093-4 